Note Open Access

\title{
Reclassification of Xanthomonas Isolates Causing Bacterial Leaf Spot of Euphorbia pulcherrima
}

\author{
Bin $\mathrm{Li}^{1}$, Rongrong $\mathrm{Yu}^{2}$, Yu Shi ${ }^{1}$, Ting Su${ }^{1,3}$, Fang Wang ${ }^{1}$, Muhammad Ibrahim ${ }^{1}$, Guanlin Xie ${ }^{1 *}$, Yanli Wang ${ }^{3 *}$ \\ and Guochang Sun $^{3}$ \\ ${ }^{1}$ State Key Laboratory of Rice Biology, Key Laboratory of Molecular Biology of Crop Pathogens and Insects, Ministry of \\ Agriculture; Institute of Biotechnology, Zhejiang University, Hangzhou 310029, China \\ ${ }^{2}$ Zhejiang University of Technology, Hangzhou 310032, China \\ ${ }^{3}$ State Key Laboratory Breeding Base for Zhejiang Sustainable Pest and Disease Control, Institute of Plant Protection and \\ Microbiology, Zhejiang Academy of Agricultural Sciences, Hangzhou 310021, China
}

(Received on June 30, 2011; Revised on November 5, 2011; Accepted on November 17, 2011)

\begin{abstract}
Bacterial leaf spot of Euphorbia pulcherrima has been reported in many countries. Characterization by polyphasic approaches indicated that the isolates from India, USA and New Zealand could be distinguished based on rep-PCR profiles and gyrB phylogenies, while the Chinese isolates should be ascribed to Xanthomonas axonopodis pv. poinsettiicola.
\end{abstract}

Keywords : bacterial leaf spot, Euphorbia pulcherrima, gyrB, rep-PCR

Bacterial leaf spot of Euphorbia pulcherrima poinsettia (BLSE), caused by Xanthomonas campestris pv. poinsettiicola, has been reported in some countries in Oceania, Asia, the Americas and Europe (Li et al., 2006b; Stravato, 2004). In China, this disease has been observed on $E$. pulcherrima in Zhejiang province (Li et al., 2005, 2006a, 2008a) and Hainan province (Li et al., 2008b). However, the BLSE isolates from India, USA and New Zealand showed differential pathogenicity reaction on Codiacum variegatum and metabolization of quinate (Vauterin et al., 1995).

Reclassification of xanthomonads has been proposed and the organisms isolated from India, USA and New Zealand, able to cause BLSE were split into three different species: Xanthomonas axonopodis pv. poinsettiicola, Xanthomonas codiaei and Xanthomonas arboricola pv. poinsettiicola (Vauterin et al., 1995, 2000). In addition, the Chinese iso-

\footnotetext{
*Corresponding authors.

Guanlin Xie

Phone) +86-571-88982412, FAX) +86-571-86971680

E-mail: glxie@zju.edu.cn

Yanli Wang

Phone) +86-571- 86404073, FAX) +86-571- 86404225

E-mail: wangylaa@yahoo.com.cn
}

lates from Zhejiang province and Hainan province showed higher similarity with the type strain of $X$. axonopodis ( $\mathrm{Li}$ et al., 2006b) and X. codiaei (Li et al., 2008b) than the type strains of other Xanthomonas species, respectively, based on sequences analysis of the 16S rRNA gene and the 16S23S rDNA intergenic spacer (ITS). However, there is little research about the relationship between the Chinese isolates and the BLSE isolates from India, USA and New Zealand.

The objective of this research was to evaluate the relationship between the causal organisms found in China and the organisms from India, USA and New Zealand based on sodium dodecyl sulfate polyacrylamide gel electrophoresis (SDS-PAGE) and rep-PCR profiles as well as sequences analysis of the 16S rRNA gene and ITS of 16S-23S rRNA and the gyrase subunit B ( $g y r B)$.

Bacterial isolates. Thirteen BLSE isolates from China, India, USA and New Zealand were used in this study (Table 1). Cultures were recovered and checked for purity by streaking on Trypticase soy broth agar (TSBA) (BBL, Becton Dickinson and Company, Cockeysville, MD) and incubating them at $28^{\circ} \mathrm{C}$ for $48 \mathrm{~h}$ aerobically. From each culture, one well-isolated single colony was picked for further cultivation and analysis. The bacterial isolates involved in this study were deposited in the culture collection of the Laboratorium voor Microbiologie, Universiteit Gent, Gent, Belgium (LMG) and the Institute of Biotechnology, Zhejiang University, China.

SDS-PAGE of proteins. Bacterial isolates were grown on nutrient agar medium (BBL, Baltimore, MD) at $28^{\circ} \mathrm{C}$ for $48 \mathrm{~h}$. Cells harvested from plates were suspended in sterile deionized water and washed twice by centrifugation at $5000 \mathrm{~g}$ for $15 \mathrm{~min}$. Approximately $25 \mathrm{mg}$ of the resulting pellet for each bacterial isolate was used for extraction and electrophoresis of total proteins using SDS-PAGE (Janse, 
Table 1. Thirteen isolates of Xanthomonas that caused leaf spot disease of Euphorbia pulcherrima were collected from China, India, USA and New Zealand

\begin{tabular}{|c|c|c|c|}
\hline Strains No. & Previous identity & Current identity & Sources \\
\hline LMG 849 & X. campestris pv. poinsettiicola ${ }^{\mathrm{a}}$ & X. axonopodis pv. poinsettiicola & India \\
\hline LMG 5401 & X. campestris pv. poinsettiicola ${ }^{\mathrm{a}}$ & X. axonopodis pv. poinsettiicola & India \\
\hline LMG 5402 & X. campestris pv. poinsettiicola ${ }^{\mathrm{a}}$ & $X$. arboricola pv. poinsettiicola & New Zealand \\
\hline LMG 5403 & X. campestris pv. poinsettiicola ${ }^{\mathrm{a}}$ & $X$ arboricola pv. poinsettiicola & New Zealand \\
\hline LMG 8675 & X. campestris pv. poinsettiicola ${ }^{\mathrm{a}}$ & $X$. arboricola pv. poinsettiicola & New Zealand \\
\hline LMG 8676 & X. campestris pv. poinsettiicola ${ }^{\mathrm{a}}$ & $X$. arboricola pv. poinsettiicola & New Zealand \\
\hline LMG 8678 & X. campestris pv. poinsettiicola ${ }^{\mathrm{a}}$ & $X$. codiaei & USA \\
\hline $\mathrm{R} 22578$ & X. campestris pv. poinsettiicola ${ }^{\mathrm{b}}$ & X. axonopodis pv. poinsettiicola & Zhejiang, China \\
\hline $\mathrm{R} 22579$ & X. campestris pv. poinsettiicola ${ }^{b}$ & X. axonopodis pv. poinsettiicola & Zhejiang, China \\
\hline R22580 & $X$. campestris pv. poinsettiicola ${ }^{\mathrm{b}}$ & $X$ axonopodis pv. poinsettiicola & Zhejiang, China \\
\hline $\mathrm{HN}-1$ & X. campestris pv. poinsettiicola ${ }^{\mathrm{c}}$ & X. axonopodis pv. poinsettiicola & Hainan, China \\
\hline $\mathrm{HN}-18$ & X. campestris pv. poinsettiicola & X. axonopodis pv. poinsettiicola & Hainan, China \\
\hline $\mathrm{HN}-20$ & $X$. campestris pv. poinsettiicola ${ }^{\mathrm{c}}$ & X. axonopodis pv. poinsettiicola & Hainan, China \\
\hline
\end{tabular}

${ }^{a}$ :Vauterin et al. $(1995,2000) . X$. codiaei from C. Variegatum was included in this study since it was able to cause the leaf spot disease of E. pulcherrima.

'Li et al. (2006b).

'Li et al. (2008b).

2006; Sahin et al., 2003). Result from this study indicated that SDS-PAGE protein profiles of the BLSE isolates tested included more than 18 reproducible bands of molecular weight ranging from 10 to more than $100 \mathrm{kDa}$ (Fig. 1). In addition, the Chinese isolates had the same profiles of protein as that of the BLSE isolates from India and New Zealand.

This study revealed that the Chinese isolates were unable to be differentiated from the BLSE isolates from other countries by SDS-PAGE protein profiles. However, Stefani et al. (1994) divided Xanthomonas campestris pv. vitians

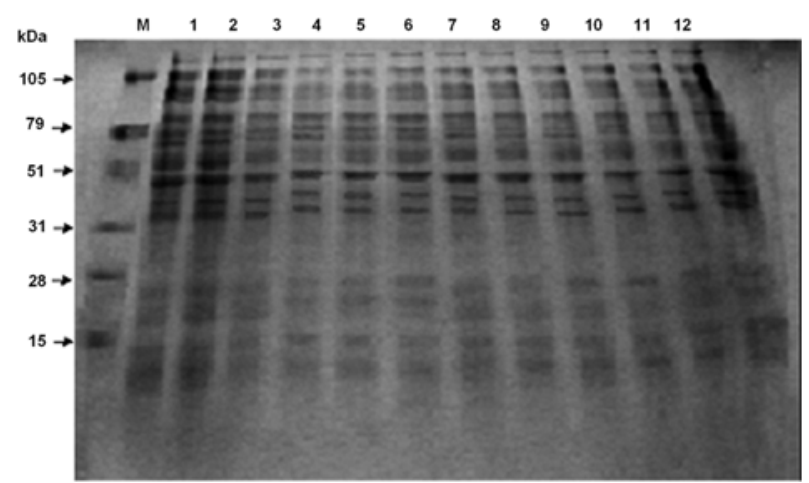

Fig. 1. Sodium dodecyl sulfate-polyacrylamide gel electrophoresis profiles of Xanthomonas isolates causing bacterial leaf spot of Euphorbia pulcherrima. $\mathrm{M}=$ protein marker (broad range, 2-150 kDa). Lanes 1-2, Xanthomonas isolates LMG 849 and LMG 5401 (India); Lanes 3-6, Xanthomonas isolates LMG 5402, LMG 5403, LMG 8675 and LMG 8676 (New Zealand); Lanes 7-9, Xanthomonas isolates R22578, R22579 and R22580 (Zhejiang province, China); and Lanes 10-12, Xanthomonas isolates HN-1, HN-18 and HN-20 (Hainan province, China). strains into two groups based on SDS-PAGE. In addition, SDS-PAGE has been used to characterize the variability among xanthomonads isolated from pistachio trees suffering from bacterial dieback in four regions of Australia (Marefat et al., 2006). Therefore, the inconsistent result may be attributed to the high degree of homogeneity within the BLSE isolates.

Rep-PCR genomic fingerprinting. The rep-PCR of bacterial isolates and horizontal agarose gel electrophoresis of the PCR products was performed as described by Gevers et al. (2001) and Sahin et al. (2003). The rep-PCR oligonucleotide primers evaluated in this study were REP1R-I (5'-IIIICGICGICATCIGGC-3') and REP2-I (5'-IIICGNCGNCATCNGGC-3'), ERIC 1R (5'-ATGTAAGCTCCTGGGGATTCAC-3') and ERIC2 (5'-AAGTAAGTGACTGGGGTGAGCG-3'), BOXA1R (5'-CTACGGCAAGGCGAC-

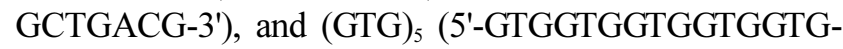
3') (Barionovi and Scortichini, 2008; Louws et al., 1995), each with its own optimal PCR program (Versalovic et al., 1994). Analysis of the rep-PCR fingerprint profiles were done using the simple matching similarity coefficient and unweighted pair group with arithmetic averages using NTSYS-pc version 2.02e (Versalovic et al., 1994; Li et al., 2010).

Patterns of PCR products for REP, BOX and ERIC primers are shown in Fig. 2A, 2B and 2C, respectively. The use of BOX, ERIC and REP primers resulted in a banding pattern containing approximately $6-9,7-11$, and 5-11 visualized PCR products, respectively (Fig. 2), while $(\mathrm{GTG})_{5}$-PCR yielded the lowest number of bands ranging 


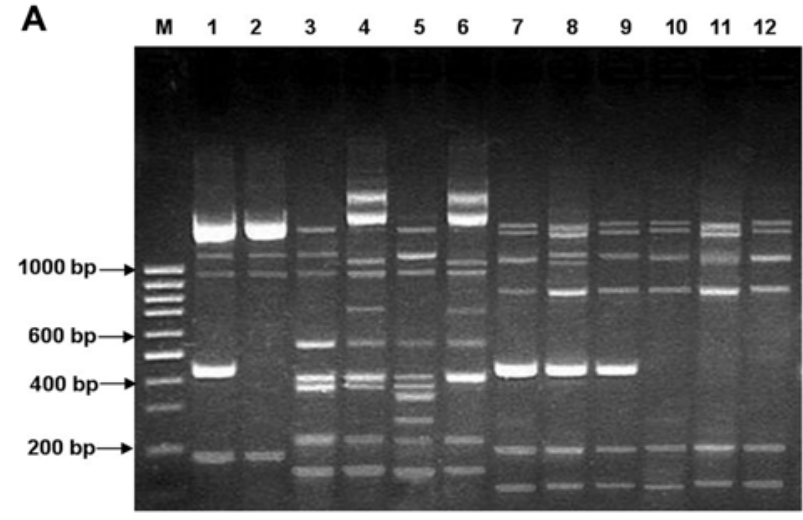

B
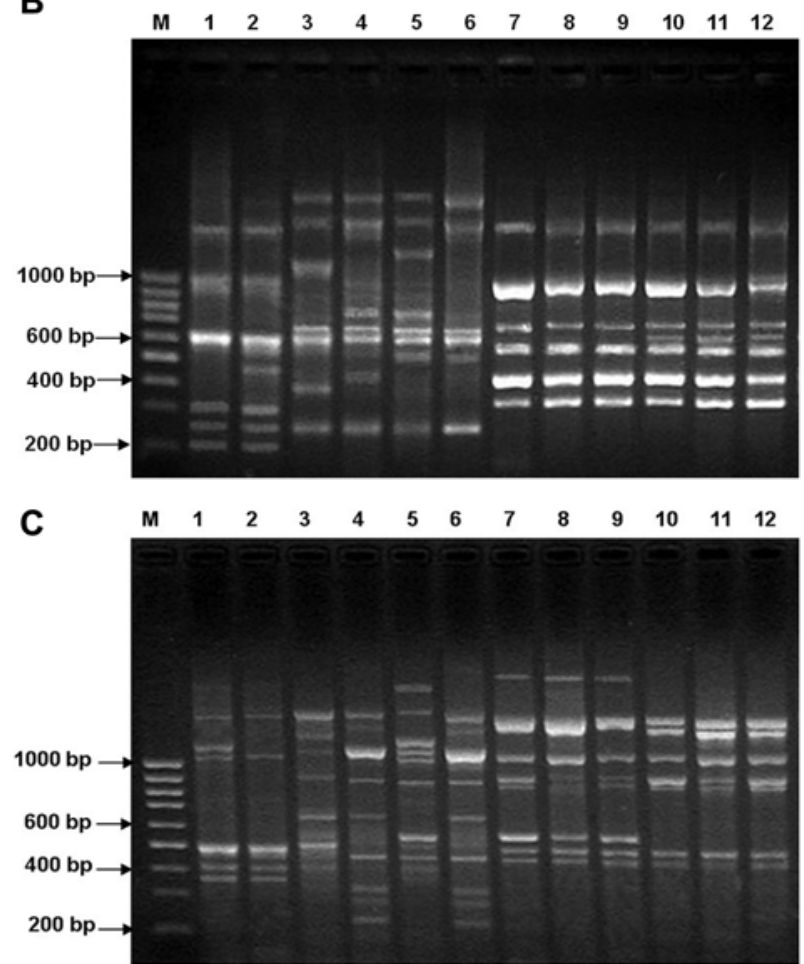

Fig. 2. Rep-PCR fingerprinting assay of Xanthomonas isolates causing bacterial leaf spot of Euphorbia pulcherrima. (A) BOXPCR; (B) ERIC-PCR; (C) REP-PCR. The DNA molecular size standard is in lane M. The Xanthomonas isolates in each lane are as follows: Lanes 1-2, Xanthomonas isolates LMG 849 and LMG 5401 (India); Lanes 3-6, Xanthomonas isolates LMG 5402, LMG 5403, LMG 8675 and LMG 8676 (New Zealand); Lanes 7-9, Xanthomonas isolates R22578, R22579 and R22580 (Zhejiang province, China); and Lanes 10-12, Xanthomonas isolates $\mathrm{HN}-1, \mathrm{HN}-18$ and $\mathrm{HN}-20$ (Hainan province, China).

from 3 to 7, and most of the BLSE isolates analysed showed less than five bands (data not shown).

The dendrogram of combined data produced using BOX, ERIC, and REP primers is shown in Fig. 3. Cluster analysis of data resulting from profiles generated by rep-PCR revealed that the BLSE isolates from China and India

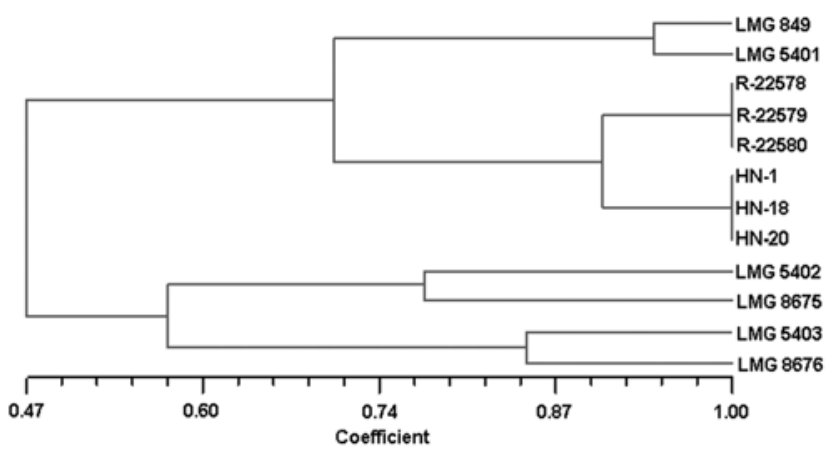

Fig. 3. Dendrogram of genetic relatedness of the combined repPCR data inferred using primers BOX, ERIC, and REP and generated by the Xanthomonas isolates causing bacterial leaf spot of Euphorbia pulcherrima. The scale indicates the degree of genetic relatedness between isolates.

clustered into one group while the BLSE isolates from New Zealand clustered into another group, and the average genetic similarity between the two groups was 0.47 (Fig. 3). Furthermore, the BLSE isolates from India formed a subgroup while the BLSE isolates from China formed the other subgroup. In addition, rep-PCR profiles of the BLSE isolates from Zhejiang province, China are somewhat different from those of the BLSE isolates from Hainan province, China (Fig. 3).

Rademaker et al. (2000) proposed that genomic fingerprinting techniques were able to truly reveal genotypic and phylogenetic relationships of Xanthomonas after the comparison of rep-PCR genomic fingerprinting with DNADNA homology. In particular, the most highly significant and consistent results were obtained by combining the data obtained from BOX-, ERIC- and REP-PCR fingerprints. Indeed, studies carried out in this study revealed that phylogenetic trees derived from BOX-, ERIC- and REPPCR genomic fingerprinting are not always identical (data not shown). Therefore, rep-PCR can be effectively used by combining the data obtained from BOX-, ERIC- and REPPCR fingerprints.

In agreement with the result of Vauterin et al. (1995), this combined result of rep-PCR using BOX, ERIC, and REP primers indicated that the BLSE isolates from India is genetically different from the BLSE isolates from New Zealand. However, the BLSE isolates were unable to be differentiated by rep-PCR with (GTG) 5 primer, which has been found to be a reliable and fast method for species identification of Lactobacillus (Gevers et al., 2001), enterococci (Švec et al., 2005), and acetic acid bacteria (Papalexandratou et al., 2009). Therefore, it could be suggested that the use of rep-PCR with $(\mathrm{GTG})_{5}$ primer for the discrimination of bacterial isolates may be dependent on the bacterial species. 
Sequencing of 16S rRNA genes, 16S-23S ITS regions and $\operatorname{gyr} \boldsymbol{B}$ gene. Total DNAs of the BLSE isolates in this study were extracted by the CTAB (Cetyltrimethylammonium Bromide) method (Li et al., 2006b). Amplification of the partial 16S rRNA genes of the BLSE isolates from India and New Zealand was performed by PCR as described by Hauben et al. (1997) using the specific primers 16F27 (AGAGTTTGATCCTGGCTCAG) and 16R1522 (AAGGAGGTGATCCAGCCGCA), while amplification of the 16S-23S ITS regions of the BLSE isolates from India and New Zealand was carried out by PCR as described by Goncalves and Rosato (2002) using the specific primers 16S uni 1330 (5'-GTTCCCGGGCCTTGTACACAC-3') and $23 \mathrm{~S}$ uni 322 anti (5'-GGTTCTTTTCACCTTTCCCTC$\left.3^{\prime}\right)$. PCR products were separated by $1.0 \%$ agarose gel electrophoresis as described by Lee et al. (2009) and were purified with a 3S EZ-Resin DNA gel purification Kit (Shenergy-Biocolor, Shanghai, China). The sequencing was performed with an $\mathrm{ABI} 3730$ automatic sequencer (Bioasia, Shanghai, China). In addition, the 16S rRNA genes and the 16S-23S ITS regions of the BLSE isolates from USA and China have been sequenced in previous studies (Goncalves and Rosato, 2002; Hauben et al., 1997; Li et al., 2006b, 2008b).

Amplification of the gyrB genes of the BLSE isolates in this study was carried out by PCR as described by Parkinson et al. $(2007,2009)$ using the specific primers X.gyrPCR2F (AAGCAGGGCAAGAGCGAGCTGTA) and X.gyrrsp1 (CAAGGTGCTGAAGATCTGGTC). PCR products were purified as described above and sequenced as described by Parkinson et al. (2007) using the primers X.gyr.fsp.s1 (GGCAAGAGCGAGCTGTA) and X.gyr.rsp3 (CTGGTCGGCGGCCAC). In addition, the gyrB genes of the BLSE isolate LMG $8678^{\mathrm{T}}$ from USA has been sequenced in previous studies (Parkinson et al., 2007).

Sequence comparison and phylogenetic analysis. Raw sequences from both strands of the PCR products were then aligned, and a consensus sequence was derived using DNASTAR 5.0 software (DNASTAR Inc., Madison, WI, USA) as described by Jeon et al. (2006, 2008). Sequence identity was confirmed by analysis using the basic local alignment sequence tool (BLAST) at the National Center for Biotechnology Information (NCBI, Bethesda, Md.). Phylogenetic analysis was performed on the 16S rRNA genes, the 16S-23S ITS regions and the gyr $B$ genes sequences of the BLSE isolates in this study and corresponding published sequences of the type strain of $X$. axonopodis (LMG 538 $)$, X. codiaei (LMG 8678 ) and $X$. arboricola (LMG $747^{\mathrm{T}}$ ) (Goncalves and Rosato, 2002; Hauben et al., 1997; Parkinson et al., 2007). Nucleotides of the 16S rRNA genes, the 16S-23S ITS regions and the

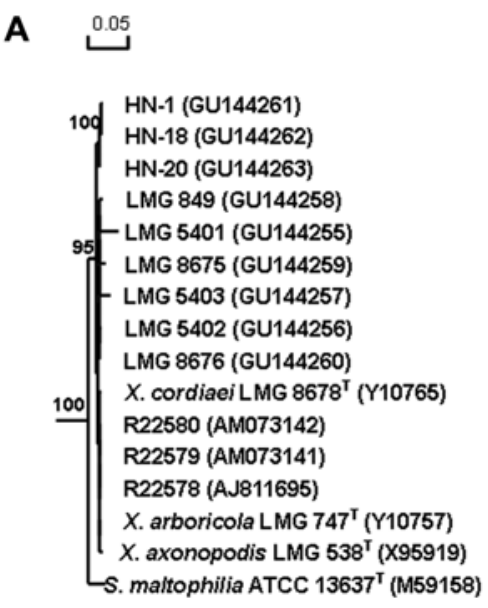

B $\stackrel{0.05}{.5}$

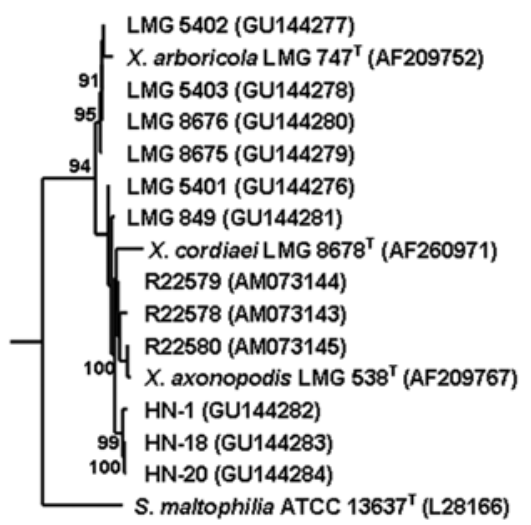

C

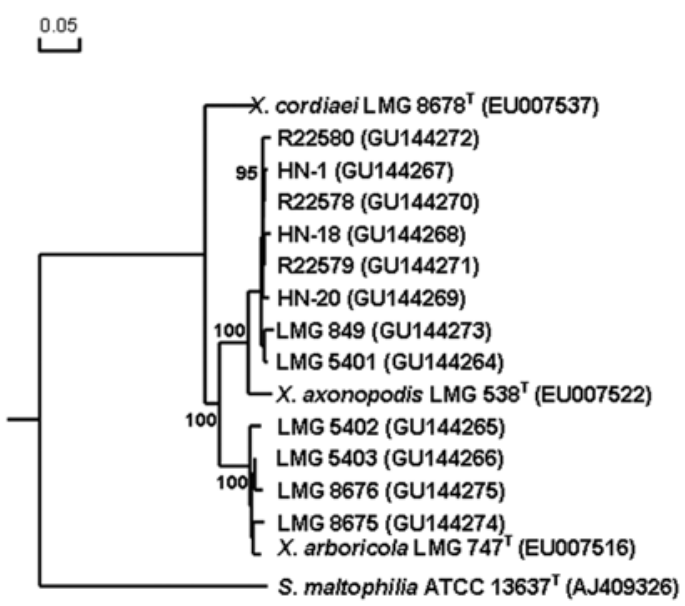

Fig. 4. Phylogenetic tree generated by the neighbor-joining method on the basis of $16 \mathrm{~S}$ rDNA sequences (A), 16S-23S rDNA ITS sequences (B) and gyrB sequences (C) showing the relationship of the Chinese isolates causing bacterial leaf spot of Euphorbia pulcherrima with the isolates from other countries. Bootstrap values (expressed as percentages of 1000 replications) are shown at major branching points. Bar, 0.05 substitutions per nucleotide position. Stenotrophomonas maltophilia ATCC $13637^{\mathrm{T}}$ was used as the outgroup. 
gyrB genes were aligned using the CLUSTAL method of MEGALIGN (DNASTAR 5.0). Phylogenetic and molecular evolutionary analyses were conducted using the software DNAMAN 6.0 (Lynnon Biosoft, Qc, Canada). Bootstrap analysis for 1000 replicates was performed to estimate the confidence of tree topology. Stenotrophomonas maltophilia ATCC $13637^{\mathrm{T}}$ was used as the outgroup.

The 16S rRNA gene sequences of the BLSE isolates were determined and aligned to that of the type strain of $X$. axonopodis, $X$. codiaei and $X$. arboricola, respectively. Result from this study indicated that the sequence similarity among the BLSE isolates varied from $95.7 \%$ to $100 \%$ while the sequence similarity between the BLSE isolates and the type strain of $X$. axonopodis varied from $95.8 \%$ to $99.4 \%$, the sequence similarity between the BLSE isolates and the type strain of $X$. arboricola varied from $96.2 \%$ to $99.8 \%$, the sequence similarity between the BLSE isolates and the type strain of $X$. codiaei varied from $96.0 \%$ to $99.7 \%$. In addition, phylogenetic analysis based on these sequences indicated that the BLSE isolates from China, India and New Zealand as well as $X$. codiaei LMG $8678^{\mathrm{T}}$, $X$ axonopodis LMG $538^{\mathrm{T}}$ and $X$. arboricola LMG $747^{\mathrm{T}}$ clustered within a group and well separated from $S$. maltophilia ATCC $13637^{\mathrm{T}}$ (Fig. 4a).

The 16S-23S rDNA ITS sequences of the BLSE isolates were determined and aligned to that of the type strain of $X$. axonopodis, $X$. codiae $i$ and $X$. arboricola. Result from this study indicated that the sequence similarity among the BLSE isolates varied from $84.7 \%$ to $99.4 \%$ while the sequence similarity between the BLSE isolates and the type strain of $X$. axonopodis varied from $86.9 \%$ to $98.1 \%$, the sequence similarity between the BLSE isolates and the type strain of $X$. arboricola varied from $88.5 \%$ to $99.2 \%$, the sequence similarity between the BLSE isolates and the type strain of $X$. codiae $i$ varied from $79.8 \%$ to $96.5 \%$. In addition, phylogenetic analysis based on these sequences indicated that the BLSE isolates from New Zealand and $X$. arboricola LMG $747^{\mathrm{T}}$ clustered within a group while the BLSE isolates from China and India as well as $X$. axonopodis LMG $538^{\mathrm{T}}$ clustered within another group (Fig. 4b).

The $\operatorname{gyr} B$ gene sequences of the BLSE isolates were determined and aligned to that of the type strain of $X$. axonopodis, $X$. codiaei and $X$. arboricola. Result from this study indicated that the sequence similarity among the BLSE isolates varied from $86.1 \%$ to $99.9 \%$ while the sequence similarity between the BLSE isolates and the type strain of $X$. axonopodis varied from $87.9 \%$ to $95.5 \%$, the sequence similarity between the BLSE isolates and the type strain of $X$. arboricola varied from $88.9 \%$ to $99.1 \%$, the sequence similarity between the BLSE isolates and the type strain of $X$. codiaei varied from $86.4 \%$ to $89.4 \%$. In addition, phylogenetic analysis of the gyr $B$ gene sequences revealed that the BLSE isolates from New Zealand and $X$. arboricola LMG $747^{\mathrm{T}}$ clustered within a group while the BLSE isolates from China and India as well as the type strain of $X$. axonopodis clustered within another group (Fig. 4c).

The analysis of 16S rRNA gene sequences indicated that the BLSE isolates from India were unable to be differentiated from the BLSE isolates from New Zealand, which is different from the result of Vauterin et al. (1995), who found that the BLSE isolates from India belong to $X$. axonopodis while the BLSE isolates from New Zealand belong to $X$. arboricola. However, this result confirmed the result of Moore (1997), who found that 16S rDNA sequence analysis is limited in terms of taxonomic resolution at the species level for members of the genus Xanthomonas.

The analysis of 16S-23S rDNA ITS sequences indicated that the BLSE isolates from New Zealand and India had high similarity with the type strain of $X$. arboricola pv. poinsettiicola and $X$. axonopodis pv. poinsettiicola, respectively. However, in this study, the BLSE isolates from China and India was unable to be differentiated from $X$. codiaei LMG $8678^{\mathrm{T}}$, which may explain the result that the BLSE isolates from Hainan province, China had higher similarity with the type strain of $X$. codiaei than the type strains of other Xanthomonas species based on sequences analysis of the 16S-23S ITS regions (Li et al., 2008b).

In comparison with $16 \mathrm{~S}$ rRNA gene sequences, the $16 \mathrm{~S}-$ $23 \mathrm{~S}$ rDNA ITS sequences of the BLSE isolates are more variable in this study, which is consistent with the result of Goncalves and Rosato (2002), who found that the 16S-23S phylogeny had greater resolution than that produced from the $16 \mathrm{~S}$ study, and have been used as a genetic marker to elucidate relationships among the Xanthomonas spp. However, neither of the two methods could be used reliably to differentiate the majority of species (Goncalves and Rosato, 2002). Thus, xanthomonad identification to species level still poses significant problems for diagnostic laboratories.

In agreement with the result of sequences analysis of the $16 \mathrm{~S}-23 \mathrm{~S}$ ITS regions, phylogenetic analysis of the gyr $B$ gene sequences revealed that the BLSE isolates from New Zealand and $X$. arboricola LMG $747^{\mathrm{T}}$ clustered within a group while the BLSE isolates from China and India as well as the type strain of $X$. axonopodis clustered within another group. This result is consistent with the result of Vauterin et al. (1995), who found that the BLSE isolates from New Zealand and India should be reclassified as $X$. arboricola pv. poinsettiicola and $X$. axonopodis pv. poinsettiicola, respectively. In addition, in this study, $X$. codiae $i$ LMG $8678^{\mathrm{T}}$ was differentiated from the BLSE isolates from China, India and New Zealand based on sequences analysis of the gyrB gene, which indicated that phylogenetic analysis of the $g y r B$ gene sequence is more discriminatory than that of the $16 \mathrm{~S}-23 \mathrm{~S}$ ITS regions. 
In comparison with the sequences of the 16S rRNA gene and the $16 \mathrm{~S}-23 \mathrm{~S}$ ITS regions, this study indicated that $g y r B$ sequencing could be used as a genetic marker to elucidate relationships among these BLSE isolates from China, India, USA and New Zealand, which provide a clearer and more standard criterion for evaluation of taxa within the BLSE isolates, and reduce problems that have previously been associated with Xanthomonas classification and taxonomy (Parkinson et al., 2009). In addition, the data is consistent with the result of Parkinson et al. (2007, 2009), who have recently constructed a phylogram from alignment of gyrase $\mathrm{B}(\mathrm{gyr} B)$ sequences for all xanthomonad species, both to indicate inter-species relatedness and as an aid for rapid and accurate species-level identification.

This study indicated that the BLSE isolates from Zhejiang province, China are somewhat different from the BLSE isolates from Hainan province, China based on rep-PCR profiles and sequences analysis of the 16S rRNA gene and the $16 \mathrm{~S}-23 \mathrm{~S}$ rDNA intergenic spacer in particular the $g y r B$ gene. The data is consistent with the result of $\mathrm{Li}$ et al. (2008c), who found that the BLSE isolates from Zhejiang province, and Hainan province, China showed differential susceptibility to antagonistic bacteria. However, there was no significant difference on the utilization of partial carbon sources between the BLSE isolates from Zhejiang province, China and the BLSE isolates from Hainan province, China (Li et al., 2008b).

Result from this study indicated that the BLSE isolates from Zhejiang province and Hainan province, China had higher similarity with the BLSE isolates from India than with the BLSE isolates from New Zealand and USA based on SDS-PAGE of proteins and rep-PCR analysis, as well as sequences analysis of the 16S rRNA gene, ITS of $16 \mathrm{~S}-23 \mathrm{~S}$ rRNA and the gyrB gene. Therefore, it could be suggested that the BLSE isolates from Zhejiang province and Hainan province, China should be ascribed to $X$. axonopodis pv. poinsettiicola.

In conclusion, these results further identified the BLSE isolates from China as $X$. axonopodis pv. poinsettiicola based on SDS-PAGE and rep-PCR profiles as well as sequences analysis of the $16 \mathrm{~S}$ rRNA gene and the 16S-23S rDNA intergenic spacer and the $g y r B$ gene. In addition, genetic divergence was observed among strains of $X$. axonopodis pv. poinsettiicola from Hainan province, China and Zhejiang province, China as well as India. Overall, this study established the initial rep-PCR profiles and gyrB phylogeny of the BLSE isolates, which could distinguish the BLSE isolates in China from those of India, USA and New Zealand.

\section{Acknowledgements}

This project was supported by Zhejiang Provincial Natural
Science Foundation of China (Y3090150), Zhejiang Provincial Project (2010R10091), the Fundamental Research Funds for the Central Universities, Specialized Research Fund for the Doctoral Program of Higher Education (20090101120083), the Agricultural Ministry of China (nyhyzx 201003029; 201003066), the Scientific Research Foundation for the Returned Overseas Chinese Scholars, State Education Ministry and Key Subject Construction Program of Zhejiang for Modern Agricultural Biotechnology and Crop Disease Control. Prof. Jean Swings is thanked for providing us with LMG strains of Xanthomonas.

\section{References}

Barionovi, D. and Scortichini, M. 2008. Integron variability in Xanthomonas arboricola pv. juglandis and Xanthomonas arboricola pv. pruni strains. FEMS Microbiol. Lett. 288:1924.

Gevers, D., Huys, G. and Swings, J. 2001. Applicability of repPCR fingerprinting for identification of Lactobacillus species. FEMS Microbiol. Lett. 205:31-36.

Goncalves, E. R. and Rosato, Y. B. 2002. Phylogenetic analysis of Xanthomonas species based upon 16S-23S rDNA intergenic spacer sequences. Int. J. Syst. Evol. Microbiol. 52:355-361.

Hauben, L., Vauterin, L., Swings, J. and Moore, E. R. B. 1997. Comparison of $16 \mathrm{~S}$ ribosomal DNA sequences of all Xanthomonas species. Int. J. Syst. Bacteriol. 47:328-335.

Janse, J. D. 2006. Phytobacteriology Principles and Practice. Wallingford, UK: CABI Publishing.

Jeon, Y. H., Chang, S. P., Kim, S. G. and Kim, Y. H. 2006. Halo blight of kudzu vine caused by Pseudomonas syringae pv. phaseolicola in Korea. Plant Pathol. J. 22:119-124.

Jeon, Y. H., Park, H., Lee, B. D., Yu, Y. H., Chang, S. P., Kim, S. G., Hwang, I. and Kim, Y. H. 2008. First description of crown gall disease on ginseng. Plant Pathol. J. 24:207-210.

Lee, Y. S., Han, H. S., Kim, G. H., Koh, Y. J., Hur, J. S. and Jung, J. S. 2009. Causal agents of blossom blight of Kiwifruit in Korea. Plant Pathol. J. 25:220-224.

Li, B., Fang, Y., Zhang, G. Q., Yu, R. R., Lou, M. M., Xie, G. L., Wang, Y. L. and Sun, G. C. 2010. Molecular characterization of Burkholderia cepacia complex isolates causing bacterial fruit rot of apricot. Plant Pathol. J. 26:223-230.

Li, B., Wang, X., Chen, R. X., Huangfu, W. G. and Xie, G. L. 2008a. Antibacterial activity of chitosan solution against Xanthomonas pathogenic bacteria isolated from Euphorbia pulcherrima. Carbohyd. Polym. 72:287-292.

Li, B., Wang, X., Yu, S. H., Xu, L. H., Zhang, H. L. and Xie, G. L. 2008b. Identification and characterization of the pathogen of bacterial leaf spot of poinsettia in Hainan province, China. Acta Phytopathol. Sinica 38:346-351 (in Chinese).

Li, B., Xie, G. L. and Swings, J. 2005. Differentiation of xanthomonads causing the bacterial leaf spot of poinsettia in China from the pathotype strain of Xanthomonas axonopodis pv. poinsettiicola. J. Zhejiang Univ. Sci. 6B:451-453.

Li, B., Xie, G. L. and Swings, J. 2006a. First report of leaf spot 
caused by Xanthomonas campestris on poinsettia in China. Plant Pathol. 55:293.

Li, B., Xie, G. L., Zhang, J. Z., Janssens, D. and Swings, J. 2006 b. Identification of the bacterial leaf spot pathogen of poinsettia in China. J. Phytopathol. 154:711-715.

Li, B., Xu, L. H., Lou, M. M., Li, F., Zhang, Y. D. and Xie, G. L. 2008c. Isolation and characterization of antagonistic bacteria against bacterial leaf spot of Euphorbia pulcherrima. Lett. App. Microbiol. 46:450-455.

Louws, F. J., Fulbright, D. W., Stephens, C. T. and de Bruijn, F. J. 1995. Differentiation of genomic structure by rep-PCR fingerprinting to rapidly classify Xanthomonas campestris pv. vesicatoria. Phytopathology 85:528-536.

Marefat, A., Scott, E. S., Ophel-Keller, K. and Sedgley, M. 2006. Genetic, phenotypic and pathogenic diversity among xanthomonads isolated from pistachio (Pistacia vera) in Australia. Plant Pathol. 55:639-649.

Moore, E. R. B., Kruger, A. S., Hauben, L., Seal, S. E., Daniels, M. J., De Baere, R., De Wachter, R., Timmis, K. N. and Swings, J. 1997. 16S rRNA gene sequence analyses and interand intrageneric relationship of Xanthomonas species and Stenotrophomonas maltophilia. FEMS Microbiol. Lett. 151: 145-153.

Papalexandratou, Z., Cleenwerck, I., De Vos, P. and De Vuyst, L. 2009. (GTG) $)_{5}$-PCR reference framework for acetic acid bacteria. FEMS Microbiol. Lett. 301:44-49.

Parkinson, N., Aritua, V., Heeney, J., Cowie, C., Bew1, J. and Stead, D. 2007. Phylogenetic analysis of Xanthomonas species by comparison of partial gyrase B gene sequences. Int. J. Syst. Evol. Microbiol. 57:2881-2887.
Parkinson, N., Cowie, C., Heeney, J. and Stead, D. 2009. Phylogenetic structure of Xanthomonas determined by comparison of gyrB sequences. Int. J. Syst. Evol. Microbiol. 59:264-274.

Rademaker, J. L., Hoste, B., Louws, F. J., Kersters, K., Swings, J., Vauterin, L., Vauterin, P. and de Bruijn, F. J. 2000. Comparison of AFLP and rep-PCR genomic fingerprinting with DNADNA homology studies: Xanthomonas as a model system. Int. J. Syst. Evol. Microbiol. 2:665-677.

Sahin, F., Abbasi, P. A., Lewis Ivey, M. L., Zhang, J. and Miller, S. A. 2003. Diversity among strains of Xanthomonas campestris pv. vitians from lettuce. Phytopathology 93:64-70.

Stefani, E., Raio, A., Bazzi, C. and Zoina, A. 1994. Identification of Xanthomonas campestris pv. vitians using SDS-PAGE. Phytopathol. Mediterr. 33:99-104.

Stravato, V. M., Carannante, G. and Scortichini, M. 2004. Occurrence of Xanthomonas axonopodis pv. poinsettiicola on Euphorbia pulcherrima in Italy. J. Plant Pathol. 86:177.

Švec, P., Vancanneyt, M., Seman, M., Snauwaert, C., Lefebvre, K., Sedláèek, I. and Swings, J. 2005. Evaluation of (GTG) $5^{-}$ PCR for identification of Enterococcus spp. FEMS Microbiol. Lett. 247:59-63.

Vauterin, L., Hoste, B., Kersters, K. and Swings, J. 1995. Reclassification of Xanthomonas. Int. J. Syst. Bacteriol. 45:472-489.

Vauterin, L., Rademaker, J. and Swings, J. 2000. Synopsis on the taxonomy of the genus Xanthomonas. Phytopathology 90: 677-682.

Versalovic, J., Schneider, M., de Bruijn, F. J. and Lupski, J. R. 1994. Genomic fingerprinting of bacteria using repetitive sequence based PCR (rep-PCR). Meth. Mol. Cell Biol. 5:2540. 